\title{
Retraction
}

\section{Retracted: The Split Common Fixed Point Problem for Quasi-Total Asymptotically Nonexpansive Uniformly Lipschitzian Mappings}

\begin{abstract}
Applied Analysis
Received 15 October 2012; Accepted 15 October 2012

Copyright (C) 2012 Abstract and Applied Analysis. This is an open access article distributed under the Creative Commons Attribution License, which permits unrestricted use, distribution, and reproduction in any medium, provided the original work is properly cited.
\end{abstract}

This article has been retracted as it is found to contain a substantial amount of material, without referencing, from the paper "The Split Common Fixed Point Problem for Total Asymptotically Strictly Pseudocontractive Mappings," Shihsen Chang, Lin Wang, Yong Kun Tang and Li Yang, Journal of Applied Mathematics, vol. 2012, Article ID 385638, 13 pages, 2012. doi:10.1155/2012/385638 [1].

\section{References}

[1] J. Na, L. Wang, and Z. Ma, "The split common fixed point problem for quasi-total asymptotically nonexpansive uniformly Lipschitzian mappings," Abstract and Applied Analysis, vol. 2012, Article ID 768591, 9 pages, 2012. 